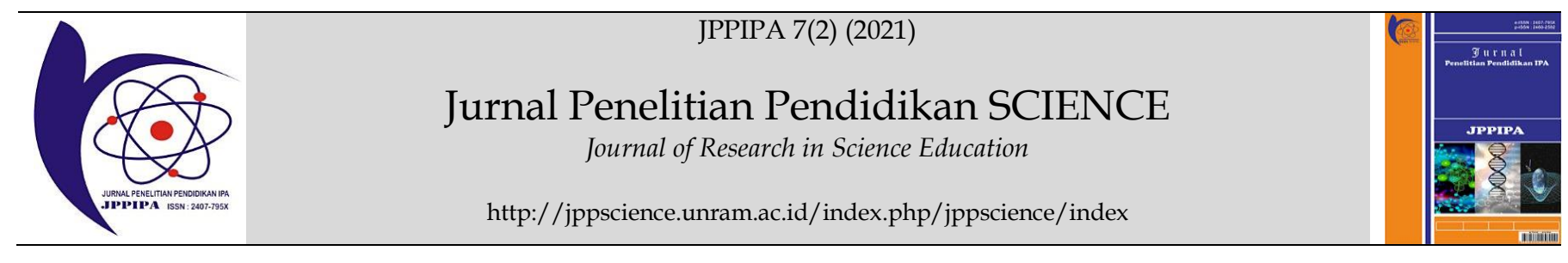

\title{
Analysis of the Impact of Smartphone Use on Adolescent Social Interactions During COVID-19
}

\author{
Mellania Indrasvari ${ }^{1}$, Risma Delima Harahap ${ }^{1 *}$, Dahrul aman Harahap ${ }^{1}$ \\ ${ }^{1}$ Biology Education, Faculty of Teacher Training, University of Labuhanbatu, Rantauprapat,Indonesia
}

DOI: $10.29303 /$ jppipa.v7i2.622

\section{Article Info}

Received : February $6^{\text {th }}, 2021$

Revised : April 1 $1^{\text {th }}, 2021$

Accepted: April 4th, 2021

\begin{abstract}
This study is titled Analysis of Smartphone Use against Adolescent Social Interactions During COVID-19. This research is motivated by the increasingly popular use of smartphones among generation $\mathrm{Z}$ that can influence social interactions especially the outbreak of the Covid-19 virus that urged students to study at home or online by using smartphones and keeping activities out of the house in order to avoid the Covid-19 virus and break the chain of the virus that causes constrained social interaction activities outside the home, especially the students of grade XII science 1 and XII science 2 at State Senior High School 2, South Rantau using qualitative-descriptive research that considered suitable for the problem of the impact of smartphone use on adolescent social interactions during the Covid19 period where the main data sources in this study are students. The tools used to collect data are questionnaires, interviews, observations, and documentation. The sampling technique used is purposive sampling. The sample data from this study were students of grade XII science 1 \& XII science 2 with a total of 64 people. The results of the interview research and supported by the questionnaire showed that the use of smartphones in students in grade XII science 1 and XII science 2 State Senior High School 2, South Rantau was at $51.02 \%$, then about $33.84 \%$ intensity of social media to eliminate saturation only activities in the house alone that resulted in a lack of intensity or association of teenagers with people around the next student doing activities gathered with friends categorized as small enough only $5.08 \%$ is also caused by the government's rules to stay at home and $10.06 \%$ of students feel the effects of smartphones. The conclusion of this study shows that there are positive and negative impacts of smartphones on adolescent social interactions during Covid-19
\end{abstract}

Keywords: Intensity of social media; smartphone usage; social interaction

Citation: Indrasvari, M., Harahap, R., \& Harahap, D. (2021). Analysis of the Impact of Smartphone Use on Adolescent Social Interactions During COVID-19. Jurnal Penelitian Pendidikan IPA, 7(2), 167-172. doi:https://doi.org/10.29303/jppipa.v7i2.622

\section{Introduction}

The era of generation $\mathrm{Z}$ which according to Grail Research (2011) is the first generation that is actually the internet generation as it is today teenagers are very pampered in the sophistication of gadgets that are smartphones to access the internet, and quality camera results so as to make it easier for teenagers to communicate remotely without meeting by using Video calls especially during The Covid-19 period that requires the whole community to stay at home in order to avoid the Covid-19 virus, the high activity in a crowded place, then a person will be easily exposed to the virus (Widyaningrum et al., 2020).

According to a survey conducted by Sladek and Grabinger, (2014) stated that generation $\mathrm{z}$ get acquainted and connect more often with various other cities and $13 \%$ in different countries, which at the beginning created smartphones to facilitate business people to launch their businesses and during the covid19 period is very helpful for business people to run their businesses. But the fact is, teenagers are very fond 
of smartphones because there are many interesting features and facilitate space in adolescent activities, and reduce boredom due to almost 1 year already students do a lot of activities at home alone, the Covid-19 pandemic makes the need to keep distance in social interactions (WHO, 2020) so that makes dependency that is difficult to release from the smartphones that ultimately make the intensity of smartphone use among them can change the pattern of social interaction (Noor 2014).

Especially in Indonesia, the use of smartphones by teenagers is very high. The Central Statistics Agency (BPS) in collaboration with the Association of Indonesian Internet Service Providers (APJII) recorded growth in Internet users in Indonesia until the end of 2013 reached 71.19 million people, an increase in 2014 reached 83.7 million people (Diarti and Sutriningsih, 2017). According to Young (2004), a person who is addicted to the internet has the intensity of internet use in the span of $40-80$ hours a week and can be up to 20 hours each time internet.

Among the teenagers in question are generation $\mathrm{Z}$ students, teenagers who are supposed to have a lot of social interaction or socialize and communicate with new people around them can be hampered a little because of the lack of free activities out of the house caused by the covid-19 virus that has spread, and smartphone use is now a major need in the era of generation $\mathrm{Z}$ especially in the age of covid-19 all activities that occur through smartphones because it will now have a negative and positive impact on their social interactions (Noor, 2014).

The advancedness of smartphones in addition to being able to be used for phones and short messages as well as regular phones, the features in an attractive smartphone allow teenagers to choose to use a sophisticated smartphone in addition to being able to use to learn smartphones can be used as entertainment because saturated activities only in the house. One of the features that become the advantages of smartphones from other mobile phones is the number of features available. this makes smartphones have a fairly high appeal, such as group chat facilities (more than one person), Video-calls or short conversation facilities through WhatsApp, Line, Twitter, Instagram, Youtube, Tiktok, and quality to take increasingly good pictures.

Teenagers who own smartphones, tend to use the internet to access their personal social networking sites that make it easier for teenagers to make new friends, and interactions become frequent through social media without meeting before, unwittingly using smartphones addicted can reduce the ability to interact socially directly (Firdaus, 2015).
In addition, using smartphones excessively can change the mindset that smartphones are more attractive than interacting face-to-face. These active smartphone users sometimes do not realize the change in their attitude towards their interlocutions in real or in front of them who see their busyness in using smartphones, It is clear that constantly like that then smartphones affect human interaction by changing the interaction directly (face to face) to indirect (Khafidli, 2013).

Basically, social interaction can be very useful for students in developing their social thinking, which concerns their knowledge and beliefs about relationship problems and social skills But According to Ameliola and Nugraha (2013) Social interactions occur through social media or indirectly make the bonds of social solidarity of students weaken.

Unwittingly, technology can reduce a person's interaction directly with the people closest to them such as during school break time students tend to secretly use smartphones to open their personal social media before covid-19 especially during covid-19 all activities using smartphones and eventually busy with their smartphones, and limiting each other's rebukes by giving smiles to friends is getting less and less, because busy themselves holding smartphones is already considered commonplace among the public today.

Every modern society has the right to use a variety of technologies. but when it comes to students how the users especially limit the use of these smartphones so as not to change the pattern of social interaction that gives a bad influence that makes students slowly more lazy to interact socially face to face well.

Based on the problems that unraveled above the researchers were motivated to conduct research, "how does the impact of smartphone use intensity on social interactions in adolescents during covid-19?" The purpose of this study is to find out the relationship between smartphone use and the intensity of social interaction.

\section{Method}

This research uses qualitative-descriptive research, using purposive sampling technique using case study method. Descriptive Research is research that is meant to collect data with the circumstances as it was at the time of the research was conducted the problems discussed in this study are considered suitable to examine the problem of the impact of smartphone use intensity on the social interaction of adolescents class XII science 1 \& XII science 2. 
Data analysis techniques are performed descriptively qualitatively using the Miles damn Huberman model. This model is carried out in 4 stages, namely: (1) Data collection is an initial data retrieval process carried out where the research takes place; (2) Data reduction shall summarize direct contact data with people, events, and situations at the research site, coding, objective logging, reflective records, make marginal records, data storage, memo creation, interlocation analysis, and temporary summary creation between locations; (3) The presentation of data of an activity understands what is happening in conducting a follow-up analysis based on understanding; (4) Verification is the stage of drawing conclusions (Miles, et al, 2013).

Researchers took place in Senior High School 2 Rantau School South Labuhan Batu Regency of North Sumatra with a class XII science population of 136 people, while the population according to Sugiyono (2014) is a generation area consisting of objects/subjects that have a certain quality and rust rustic set by researchers to draw conclusions. whereas according to (Riduwan, 2012) the sample is part of the population in this study the total number used as many as 64 people from class XII science 1 which amounted to 32 people \& XII science 2 amounted to 32 people. Data collection techniques used in this research are observations, interviews, documentation, and questionnaires or questionnaires as supporting data, observations, and questionnaire, documentation used is designed based on a Likert scale that contains a number of questions about the object to be disclosed. The measurement scale of questionnaires used in this study is a Likert scale model using 4 options consisting of: strongly agree, agree, disagree, strongly disagree, strongly disagree, in the questionnaire, there are positive statements (favorable) and negative statements (less good). The Likert scale is used to measure one's attitudes, opinions, and perceptions of social phenomena (Sugiyono, 2014). It is therefore considered suitable for students to know.

\section{Result and Discussion}

This research has been conducted at State Senior High School 2, South Rantau. Researchers took a sample of research in State Senior High School 2, South Rantau class XII science 1 which amounted to 32 students, and XII science 2 which amounted to 32 students. So the total sample is 64 people. This study provides the same between class XII science 1 and XII science 2 in State Senior High School 2, South Rantau.
Researchers conducted a questionnaire at State Senior High School 2, South Rantau and conducted interviews to collect the documents needed to complete the research.

Data from the research obtained from 64 students, all can answer the questions in the questionnaire. This is because it disseminates questionnaires through google forms that can be filled by students anytime and anywhere even though students cannot attend school because of government rules to study at home online in order to reduce the spread of covid-19 to students that are happening in Indonesia and in the world.

The results obtained from the questionnaire answers on the implementation of research from students of State Senior High School 2, South Rantau as much as $51.02 \%$ of students use smartphones every day especially since the outbreak of covid-19 more and more often students use smartphones, which means that students can not be separated from their smartphones. In addition, as much as $33.84 \%$ of the intensity of smartphone use in social media is approximately 6 hours per day due to the saturation of students' only activities at home. furthermore, $5.08 \%$ of students use their time to gather with their friends while carrying their smartphones and rarely done because PSBB rules and keeping distance supported by Videlia, (2020) break the chain of transmission can be done with PSBB and stricter enforcement of the rules. And as many as $10.06 \%$ of students who feel the effects of smartphones tend to be negative.

Data and facts show the results that smartphones become gadgets owned by all students of grade XII science 1 and XII science 2 at State Senior High School 2, South Rantau. According to the homeroom teacher in an interview during the observations, almost all of the students own and use smartphones. This information was confirmed by the results of questionnaires or questionnaires distributed by researchers to 64 students in grades XII-science 1 and XII science 2. The results showed that as many as ( $51.02 \%$ ) students use their smartphones every day that is in a high category especially since the covid-19 outbreak enters Indonesia all activities, interacting, learning is on a smartphone, supported by the statement of research results (Sharen, 2015) the use of Gadgets reached 50\% and above which shows that the use of Gadgets falls into the high category. They become lazy to socialize with the surrounding environment, they are lazy to go anywhere and lazy to do their duty to worship.

According to Carbonell, et al, (2018), several factors can influence the use of smartphones against students, namely: (1) The sophistication of 
smartphones, (2) Smartphones that always bring up the latest features, (3) Environment that creates pressure on students both from peers and from society.

And the use of this smartphone can affect the ability to interact with people around him, in accordance with the opinion (Pebriana, 2017) that the use of smartphones, which is carried out every day for a long period of time will cause the child to become introvert. This is also supported by the opinion (Agusta, 2016) that teenagers are the highest consumers in terms of purchases and use of smartphones.

Data results from the questionnaire about the intensity of smartphone use in social media students also showed the number of $(33.84 \%)$ intensity of smartphone use has a significant effect on communication behavior (Gifary \& Kurnia, 2015) using more than 6 hours per day of his Smartphone. it is undeniable that the psychological state is used as an excuse to social media during covid-19, according to the results of interviews with students through videocalls that social media can be used as an escape from all online learning activities at home. almost all smartphone usage occurs outside the school and in the school environment even though the school only enters 2 times a week and there is a rule not to bring smartphones into the school environment proven according to the results of interviews with the class parents XII science 1 and XII science 2 that every raid there is still a Smartphone raided by ethics teachers this is supported by (Suryanto, 2011) that teenagers use their smartphones almost every day at home, in the play environment, while in class in learning activities even to drive According to the World Health Organization (WHO, 2013), road traffic accidents become the leading cause of death 9 th and $2.2 \%$ of global deaths at least 1.6 million traffic accidents each year involving drivers using mobile phones.

The use of this smartphone is still used by students as accessing social media through the features on their respective Smartphones. It is also agreed with (Anandio et al, 2018) that students use smartphones to access social media, browse, and play games, and supported by opinions (Lioni, 2014) namely there are several general futures contained in smartphones, among others: (1) Video call, (2) internet, (3) telephone, (4) wifi, (5) camera, (6) Bluetooth, especially in the time of Covid-19 Video call is important for social interaction to treat longing with people far and near.

From the results of research interviews with students that they tend to use WhatsApp to communicate, video-call to conduct social interactions remotely and closely because it becomes the best alternative to social interaction with new people and friends, As revealed (Ngasiah, 2016) suggested that social media such as WhatsApp is a media platform that focuses on the existence of users who facilitate them in activities and collaborate with many people even if only one click of the message.

Based on the results of interviews with students they do intensive gatherings with friends only in the school environment when there is a schedule to collect tasks offline if there is a gathering with friends outside the school only on weekends and because of the covid19 outbreak gathering with friends is very rare because of the ban on parents even if out must really maintain the health protocols recommended by the government. even if gathered many who like to use smartphones to take pictures, and update their social media status, it also agrees with (Chastanti et al, 2019) that is for students who have social media usually only post about their personal activities, their vent, and photos with friends.

This is confirmed by a poll obtained by $5.08 \%$ of students doing activities gathered with their friends showed a fairly low number resulting in a decrease in the quality of social interaction directly. So that by itself makes students forget to communicate and interact with their friends and the surrounding environment (Simamora, 2016).

Even from some of them like and comfortable interacting through social media than interacting directly even though they have never met at all, social interactions that are done indirectly have a different impact on face-to-face communication. This is supported by a statement (Ameliola and Nugraha, 2013), social interaction indirectly causes failure to communicate with each other, in the sense that the recipient captures the meaning of the message is different from that intended by the sender.

Excessive use of smartphones to forget the time in using smartphones until late at night can have a less good effect especially the average activity of social media connoisseurs to interact socially is carried out at night this activity is more common due to school holidays due to covid-19 which does not require students to get up early. But from the questionnaire spread by researchers can be seen that obtained is 10.06 $\%$ who feel the negative impact of smartphones from the results of interviews with students who experienced a negative impact almost on average feel the effects of fatigue on the eyes so that it will adversely affect health. A number of studies revealed the adverse effects of smartphones on health are, lack of motion, difficulty sleeping, disturbances in the eyes, ability to socialize reduced, aggressive, exposure to radiation and give an opiate effect (Alhady et al, 2018) and will give an adverse effect, impacting the risk of attention center disorders and hyperactivity according to (Setianingsih, 2018). 


\section{Conclusion}

Based on data analysis and discussion in the previous chapter, the conclusion of this research data is the Covid-19 Virus that is sweeping the world, which includes our country is Indonesia That the use of smartphones in students grade XII science 1 and XII science 2 State Senior High School 2, South Rantau is at $51.02 \%$, then about $33.84 \%$ intensity of smartphone use in social media to reduce saturation in activities only in the house that results in a lack of intensity or association of teenagers with people around and on finally providing convenience of social interaction through social media will give a positive and negative impact of smartphones to the social interaction of teenagers then students do activities to gather with friends only $5.08 \%$ categorized as small enough to be limited to the government rules to stay at home in order to break the chain of Covid-19 virus and 10.06\% of students feel the negative effects of smartphones that is fatigue in the eyes although quite a few who feel the negative effects of smartphones should still limit the use of smartphones.

\section{Acknowledgments}

Thank you to God Almighty, who has given me the health to complete this research and I would like to thank my parents who have given me the spirit to motivate me and I also love my supervisor who has helped me finish this research and not forgetting I thank my friends who always give help in my research.

\section{References}

Agusta, D. (2016). Risk Factors for Addiction using smartphones in students. Yogyakarta. The State University of Yogyakarta.

Alhady, C., Salsabilla,F.A., \& Azizah, N. N. (2018). The use of smartphones in the construction of learning Students Mts Negeri 7 Model Jakarta. Al-Izzah: Jurnal Hasil-Hasil Penelitian. 13(2). doi:http://dx.doi.org/10.31332/ai.v13i2.975

Ameliola, S., \& Nugraha, D.H. (2013). Development of Information Media and Technology towards children in the Global Era. Proceeding to the 5th international conference on Indonesian studies: Ethnicity and Globalisation. Pdf (downloaded January 3, 2020).

Anandio, K., Rosmawati., Umari, T. (2018). Gadget Questions And social Interaction In school SMK Muhammadiyah 2 Pekan Baru. JOM FKIP. 5(1), $1-12$.
Bayu, F. (2015). The impact of smartphone use on social interaction among students majoring in sociology of religion, Faculty of Unsuhulludindan Islamic Thought. Thesis. Yogyakarta: Sunan State Islamic University kalijaga Yogyakarta.

Carbonell, X., Chamarro, A., Oberst, U., Rodrigo, B., \& Prades, M. (2018). Problematic Use of the Internet and Smartphones in University Students: 20062017. International journal of environmental research and public health, 15(3), 475. https://doi.org/10.3390/ijerph15030475

Chastanti, I., Gultom, M., \& Sari, N. F. (2020). Analysis of Internet Usage of Friendly/Communicative Character in Biology Learning. Jurnal Pelita Pendidikan, 7(4). https://doi.org/10.24114/jpp.v7i4.15421.

Diarti, E., Sutriningsih, A., \& Rahayu H, W. (2017). The Relationship between Internet Use and Sleep Pattern Disorders In Psik Unitri Malang. Nursing News, 2(3), 321-331.

Firdaus, B. (2015). The Impact of Smartphone Use on Social Interactions among Students of the Department of Sociology of Religion, Faculty of Unsuhulludindan Islamic Thought. Thesis. Yogyakarta: State Islamic University Sunan Kalijaga Yogyakarta.

Gifary, S., \& Kurnia N.I. (2015) The intensity of smartphone use and communication behavior (study on smartphone use among Students of Communication science study program. Telkom University). Journal of sociotechnology, 14 (2), 170178.

https://doi.org/10.5614/sostek.itbj.2015.14.2.7.

Grail Research. (2011). Consumers of Tomorrow Insights and Observations About Generation Z. Retrieve from:http://www.integreon.com/pdf/blog/con sumers_of_Tomorrrow_Insights_and_Observatin s_About_Generation_Z_246.pdf be accessed on January 20, 2020, at 11:52 a.m.

Khafidli, F.M. (2013). The Influence of Smartphones on Student Social Interaction in Tangerang City. Anima, Indonesian Psychological Journal, 28 (1), 131-142.

Lioni, T., Holillulloh, \& Nurmalisa, Y. (2014). The Effect of Gadget Use On Learners On Social Interactions. Jurnal Kultur Demokrasi, 2(2). Retrieve from: http://jurnal.fkip.unila.ac.id/index.php/JKD/ar ticle/view/4220/2612

Miles, M., Huberman, M., \& Saldaña, J. (2013). Qualitative Data Analysis: A Methods Sourcebook. In Zeitschrift fur Personalforschung (Vol. 28) 
Noor, F. (2014). Analysis of Smartphone Use in Friendship In Grade X School at Senior High School 4 Palangkaraya School Year 2013/2014. Thesis. Palangkaraya: University of Muhammadiyah Palangkaraya.

Pebriana, P. (2017). Analisis Penggunaan Gadget terhadap Kemampuan Interaksi Sosial pada Anak Usia Dini. Jurnal Obsesi : Jurnal Pendidikan Anak Usia Dini, 1(1), 1-11. doi:https://doi.org/10.31004/obsesi.v1i1.26

Riduwan, A. (2012). Formulas and data in statistical applications. Printed I. Bandung: Alfabeta.

Setianingsih, S. (2018). The impact of gadget use on preschool-age children can increase the risk of attention-centering disorders and hyperactivity. Gaster, 16 https://doi.org/10.30787/gaster.v16i2.297

Simamora, A.B.C. (2016). Perception of parents on the impact of gadget use on children of primary education age in Bukit Kemiling Permai Housing District Kemiling Bandar Lampung. Lampung: University of Lampung

Sladek, S., \& Grabinger, A. (2014). Gen Z: The first generation of the 21st Century has arrived, Retrieve from:http://xyzuniversity.com/wpcontent/uplo ads/2014/02/GenZ_Final.pdf. retrieved on January 19, 2020

Sugiyono. (2014). Quantitative Qualitative Research Method and RED. Bandung: CV Alfabeta.

Suryanto. (2011). Methodology and Application of intelligence research. Bandar Lampung: Mulia Medika.

Videlia, D. (2020). The Meaning of PSBB Created to Prevent the Spread of Corona in Indonesia, Retrieve from:

https://www.google.com/amp/s/amp.tirto.id/ art -psbb-yang- made-to-prevent-spread-coronain-indonesia-eMXT. Retrieved 2 February 2021.

WHO. (2013). Road Traffic Injuries. Retrieve from: http://www.who.int. retrieved January 27, 2020

Widyaningrum, N., Djayanti, P,Y., \& Wilopo. (2020). Image of physical distancing as an effort to suppress the spread of covid-19 in the province of special region of Yogyakarta. NUSANTARA: journal of social sciences, 7(2), 470-481

Young, K. S. (2004). Internet Addiction A New Clinical Phenomenon and Its Consequences. American Behavioral Scientist, 48 (4), 402-415. doi: https://doi.org/10.1177/0002764204270278 